\title{
Biogas Technology as an "Engine" for Facilitating Circular Bio-Economy in Denmark-The Case of Lolland \& Falster Municipalities Within Region Zealand
}

\author{
Rikke Lybæk ${ }^{1,2 *}$ and Tyge Kjær ${ }^{1,2}$ \\ ${ }^{1}$ University of Roskilde (RU), Roskilde, Denmark, ${ }^{2}$ Institute of People and Technology Universitetsvej 1, Roskilde, Denmark
}

OPEN ACCESS

Edited by:

Elizabeth Almeida Duarte, University of Lisbon, Portugal

Reviewed by: Marian Kazda,

Ulm University, Germany

Biplab Kumar Debnath,

National Institute of Technology

Meghalaya, India

${ }^{*}$ Correspondence:

Rikke Lybæk

mailto:rb/@ruc.dk

Specialty section: This article was submitted to

Bioenergy and Biofuels,

a section of the journal Frontiers in Energy Research

Received: 15 April 2021

Accepted: 25 June 2021

Published: 06 August 2021

Citation:

Lybæk R and Kjær T (2021) Biogas Technology as an "Engine" for Facilitating Circular Bio-Economy in Denmark - The Case of Lolland \&

Falster Municipalities Within

Region Zealand.

Front. Energy Res. 9:695685.

doi: 10.3389/fenrg.2021.695685
This article investigates how biogas technology can facilitate the deployment of municipal circular bio-economic solutions within the energy and agrarian sectors in Denmark. The emphasis is on the regional climate policy and the existing biogas technology concepts, within a decentralized energy market located in the Southern part of Zealand. The case analysis will identify how such technology can be utilized as a lever for future "extractionactivities," as for example protein, wax, and furfural substrates. Within Falster \& Lolland Municipalities, it is identified that 800.000 tons of animal manure is readily available for biogas production, just as 880.000 tons and 220.000 tons of unused beet tops and residual cereal straw could be feed to biogas facilities as for example co-silage materials. With a potential gas yield of approximately $897.000 \mathrm{MWh}$, composed by the crop residues alone, the challenge is how to utilize such resources the most efficient when addressing future needs for bio-products and high value materials and energy. Through the lens of Circular Bio-Economy this article addresses three themes, by which biogas technology can become an "engine" for future bioenergy solutions, where cascading activities and use of side-streams are developed: 1) production of biogas by means of local agricultural residues (beet tops, residual straw, and animal manure), combined with 2) "extractionactivities" as furfural and wax from straw, as well as protein from beet tops. Besides this 3) opportunities for upgrading the biogas and distributing it on a natural gas network, hereby enlarging the supply market for energy services from the biogas plant and facilitating the development of a more "integrated energy system," currently being promoted by the European Commission. This article concludes on a step-by-step approach to utilize biomass residues more efficiently in light of the CBE concept and cascading approach, and the available biomass resources within the specific case area addressed.

Keywords: biogas, circular bio-economy, cascading, bio-products, agricultural residues 


\section{INTRODUCTION}

Biogas technology has been a part of the energy supply system in Denmark since the late 1970s, where the first farm biogas plants were implemented as a result of the oil crises (Rüdiger, 2014), mainly as manure-based plants for the production of heat to the farm stable and house substituting the import of fuel oil (Beuse, 2000). Since then, the technology has developed to become very large farm biogas plants, as well as centralized biogas plants with several hundreds of livestock farmers connected to the facility, with the supply of district heating to the local community and power to the grid (Raven and Gregersen, 2007; Lybæk et al., 2013). Today, most newer biogas plants also produce upgraded biogas to the gas grid, which are distributed to households and industry sometimes over long distances (Holm-Nielsen et al., 2009; Dansk Gasteknisk Center, 2020). As of 2020, there are implemented 64 farm biogas plants and 36 centralized biogas plants in Denmark, besides 51 plants operated in connection with wastewater treatment, with an energy production of $20 \mathrm{PJ}$ (Danish Energy Agency DEA, 2020a), where two-thirds of the gas is upgraded to natural gas standard (Food and Bio Cluster Denmark, 2020). The manure-based plants digest approximately 16 million tons of animal manure on an annual basis (total manure production 40 million tons), together with different types of substrates in the production of biogas, hereunder various types of sorted household waste, industrial waste, and agricultural residues (Al Seadi et al., 2013a; Food and Bio Cluster Denmark, 2020).

Traditionally, most biogas plants have been implemented in Jutland where the sandy soil and the majority of the livestock animals have been situated. But due to intensified climate policies, other parts of Denmark are looking to increase their biogas production, hereunder Region Zealand, which cover most parts of the island of Zealand except for the area around the capital of Copenhagen. Based on various EU directives (e.g., renewable energy directive, energy efficiency directive, energy taxation directive) three national political targets from the Danish "Energy Deal 2018" (Danish Ministry of Climate, Energy and Utilities, 2018) have especially been strong drivers for this change, requiring that 1) renewable energy must count for $55 \%$ of the energy supply in 2030 with special targets for power and district heating, ii) the consumption of power must be $100 \%$ renewable in 2030 , and 3) at least $90 \%$ of the district heating must be renewable in 2030. Besides this, the "Climate Deal Energy and Industry 2020 " also impacts the development, requiring $\mathrm{CO}_{2}$ emission reductions of $70 \%$ compared to the 1990 level (Danish Ministry of Climate, Energy and Utilities, 2020).

In Region Zealand-located on the island of Zealand in the Eastern part of Denmark-the national Danish climate targets have been adopted to strategic plans of how to reach $\mathrm{CO}_{2}$ emission reduction targets of 4.1 million tons of $\mathrm{CO}_{2}$ annually, constituting to $70 \% \mathrm{CO}_{2}$ reduction within the region compared to the 1990 level. Especially four main areas are emphasized, which could lead to 3.1 million tons of $\mathrm{CO}_{2}$ reductions annually within the region (or to $77 \%$ of the target of 4.1 million to be reached by 2030). These are as follows: 1) electricity: $100 \%$ of the electricity consumption must rely on renewable energy leading to 1.3 million tons of $\mathrm{CO}_{2}$ emission reductions; 2) gas grid: increase biogas production corresponding to 0.7 million tons of $\mathrm{CO}_{2}$ emission reductions; 3) fossil fuels: substitute natural gas and oil from "oil-villages" (Dansk Energi, 2017) with renewable energy equal to a reduction of 0.8 million tons of $\mathrm{CO}_{2}$ emissions annually; 4) transport: from electric cars 0.3 million tons of $\mathrm{CO}_{2}$ emission reductions are finally expected to be achieved before 2030. Within the area of biogas specifically, the target is to reach 120 million $\mathrm{m}^{3}$ methane gas (biogas) and to achieve 711.200 tons of $\mathrm{CO}_{2}$ emission reductions by implementing new biogas capacity (Fælles Regional Energiomstilling, 2020). Region Zealand see the biogas technology as pivotal for the transitions of the energy supply, due to the three aspects presented in the following.

"Production and distribution of energy in the form of gas" is important in the future. It will substitute the use of oil and natural gas for individual heating and hence lower the current demand from 235 million $\mathrm{m}^{3}$ to $90 \mathrm{~m}^{3}$ million biogas $\left(83\right.$ million $\mathrm{m}^{3}$ methane). But, as the heavy transport sector converts to gas, and the need for gas from biogas and other green gasses increases, biogas - as a stabilizing energy carrier-will also increase due to a higher integration of fluctuating energy sources, as, e.g., wind and solar. Thus, besides 25.6 million $\mathrm{m} 3$ biogas (methane) used for Combined Heat and Power (CHP), plus the existing upgrading capacity of 54.7 million $\mathrm{m}^{3}$ biogas (methane), Region Zealand need to deploy new biogas capacity equal to 120 million $\mathrm{m}^{3}$ biogas (methane) over the next years. Two biogas plants are hence scheduled to be implemented within Lolland and Falster Municipalities. These plants are expected to be able to sustain the natural gas network within Region Zealand, which has and still poses heavy sunk costs connected to the distribution of energy and will hence utilize and benefit from the large investments in this infrastructure (Dansk Gasteknisk Center, 2019; 2020).

"Increases in the capabilities of integrating fluctuated energy sources" is another important factor that Region Zealand emphasis in connection with biogas. It is for example suggested that the existing gas network is converted from the present "natural gas system" to a comprehensive "regional integrated green gas supply network," where various energy producers can feed in their renewable energy, as, e.g., hydrogen made from wind turbine electricity (PtX) (Fuel Cell Bulletin, 2020), as the gas network will be able to contain up to $20 \%$ hydrogen. Various energy producers and consumers will thus benefit from the biogas and other green gasses stored and distributed in the gas pipe network (Fælles Regional Energiomstilling, 2020). Such "integrated energy systems" are also emphasized by the EC in their communication "Powering a climate-neutral economy: An EU Strategy for Energy System Integration" (2020), in which they propose to develop "energy system 'as a whole,' across multiple energy carriers, infrastructures, and consumption sectors" (European Commission, 2020).

Finally, Region Zealand also emphasize "contributing to the agricultural sector's climate actions" being a basically agrarian region. 7.1 million tons of $\mathrm{CO}_{2}$ emissions are caused by agricultural activities in Denmark annually, where this figure is 
1.3 million in Region Zealand. The scheduled expansion of biogas with 120 million $\mathrm{m}^{3}$ will lead to 782.500 tons of $\mathrm{CO}_{2}$ emission reductions, and account for 389.100 tons of the $\mathrm{CO}_{2}$ emission reduction targets posed on the agricultural sector within the Region. Hence, by achieving the planned biogas capacity of 120 million $\mathrm{m}^{3}$, around one-third of the reduction targets can be achieved (Fælles Regional Energi-omstilling, 2020). This is due to the fact that the biogas technology not only produces renewable energy, which substitutes fossil fuels, but also reduces leakages of methane from farm manure storage tanks, and due to the fact that lower quantities of methane losses occur when distributing the manure on the soil due to the more plant accessible fertilizer (Jørgensen, 2009; Al Seadi et al., 2013b).

As illustrated in the previous, Region Zealand plan to benefit highly from biogas technology to provide a carbon neutral energy supply, which is flexible and integrates future fluctuating energy sources, just as the technology will assist the agricultural sector in achieving its climate targets. This article thus investigates whether or not this part of Denmark holds sufficient biomass resources, to be used as feedstock for biogas production, to sustain such ambitions. It further investigates, how the biomass resources should be utilized the most efficient in which type of technology application. Analysis of how mature and reliable biogas technology, prepared to be utilized for gradually more complex bio-products in the future, will hence be emphasized. This is especially important in the light of growing pressure on bio-resources for energy production and various bio-services (Gylling et al., 2012; Malico et al., 2019). Focus will also be on what type of bio-products or "building blocks," which can be produced, at the suggested biogas plants at Lolland \& Falster Municipality, when looking at the available biomass residues. Thus, this article access by which steps such resources could be utilized for bio-products and higher value materials and energy, and correspondingly, according to which methods. This is emphasized by drawing on knowledge obtained from the research project: "BioBIGG - Bioeconomy in the south Baltic Area: Biomass-based Innovation and Green Growth," financed by Interreg South Baltic and Region Zealand, emphasizing biomass resources and potential biogas systems within this specific geographical area.

This article now proceeds with an outline of the methodologies applied in this study starting with a presentation of the Circular Bio-Economy concept and cascading approach adopted as theoretical frameworks in this research. It then continues with a presentation of the production of wax, furfural, and proteins as important future bio-products, to facilitate a better understanding of the result section presented later in this article. Finally, the article elaborates on the data retrieval, including the case study area composed by Lolland \& Falster Municipalities within Region Zealand.

\section{MATERIALS AND METHODS}

\section{Circular Bio-Economy}

The European Union strongly emphasizes the concept of bioeconomy and member state countries, and other countries around the World have adapted this concept in their biomass policies nationally (Fund et al., 2018). The definition of BE is "production of renewable biological resources and the conversion of these resources and waste streams into value added products, such as food, feed, bio-based products and bio-energy" (European Commission (EC), 2012). The concept has however received critique for not being circular and sustainable and merely applying business-as-usual (Hetemäki, et al., 2017; Pfau et al., 2014), where circular economy (CE) is defined as "minimizing the generation of waste and maintaining the value of products, materials and resources for as long as possible." Thus, the two concepts above have been merged by the EU to Circular BioEconomy, and the European Commission have stated that BE to a larger extent must have a circular focus to become fruitful (European Commission (EC), 2018).

The CBE concept is thus relatively new and the role of the concept in a future green transition is not fully defined or exemplified at the local and regional levels (Stegmann et al., 2020). This research will contribute to the lack of knowledge of how to adopt and apply this concept in a local context emphasizing the opportunity for using biomass residual from the Danish agricultural sector to speed up the pathway for green transition. By using cereal and beet tops residues, as well as animal manure, it illustrates and exemplifies how to utilize biomass residues from the agricultural sector, which otherwise could be wasted. The article will highlight how these residual waste streams can be valorized and utilized, by producing nutrients, renewable energy, and bio-products through upgrading and cascading methods (Sirkin, 1990; Sirkin and ten Houten, 1994). Such contributions are, according to Stegmann et al. (2020), underrepresented in the current CBE literature.

The thinking of this approach is depicted in Figure 1, showing the CBE system (green part of the triangle), "disrupting" the traditional carbon cycle system with a long timeframe (gray part of the triangle). The orange arrows illustrate the focal point of investigation in this article-a future green transition pathway-in which upgrading and cascading production methods (orange bend arrows) are intensified and developed further within the energy sector using agricultural residues. This is facilitated by the biogas technology that acts as an "engine" for CBE activities within the local community. Enhancing the biomass carbon cycle system, by using residues from the agricultural sector currently being treated as waste, to provide bio-product extraction activities and upcycled materials and energy, is thus the overall emphasis of this article. These resources must be utilized more efficiently, together with other local natural resources such as for example solar and wind energy, as well as geothermal energy, however not being a part of this investigation.

Resource cascading-normally just referred to as cascading-is a central method for optimizing the use of resources in the $\mathrm{CBE}$. Cascading can be described as the use of outputs from one process, as an input to a sequential process at another level in the cascade chain, with the aim of extending the overall utilization time and maintaining the resource quality (Sirkin, 1990). At every level in the cascading chain, three 


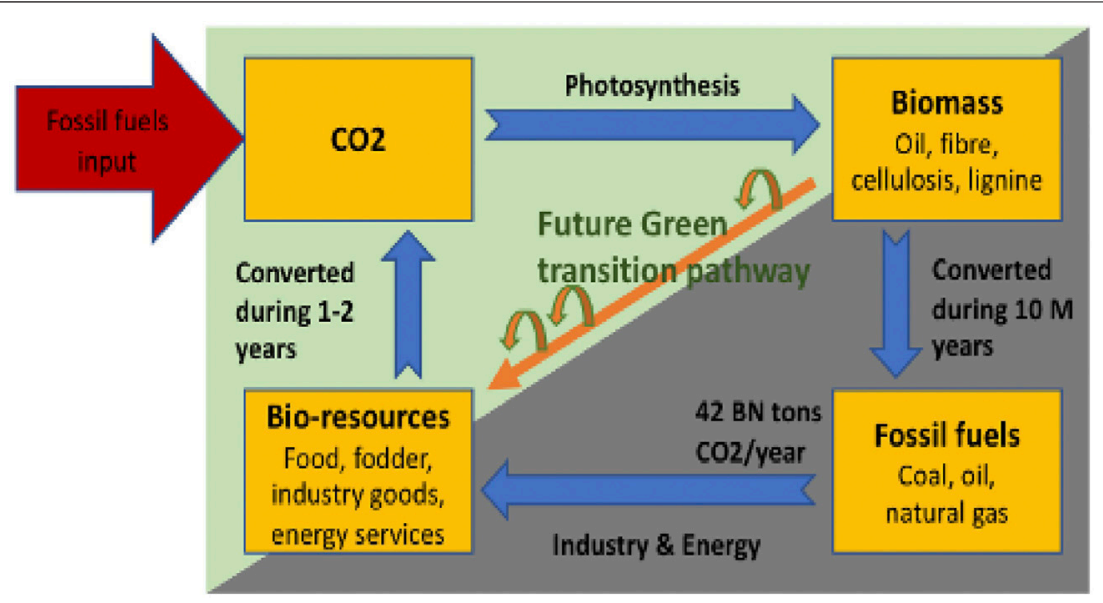

FIGURE 1 | Future Green transition pathway adapting a CBE approach through upgrading and cascading production methods, which "disrupt" the traditional fossil fuel carbon cycle. Data adopted from: IPCC et al. (2013).

options need to be the addressed 1) Upgrade or upcycle the resource to a higher level in the same cascading chain or in a new cycle, 2) Cascade the resource to a next (lower) level in the cascading chain, or 3) Maintain the resource quality at the same utility level (Sirkin and ten Houten, 1994). This study mainly provides suggestions of how to apply upgrading/upcycle to higher levels-or to new cycles-in the cascading chain, thus being option number one.

When applying the cascading concept to the utilization of cereal straw and beet tops, bio-products will provide an upgrading of the agricultural residues to a higher level, just as the production of upgraded biogas will enable cascading of the generated energy to new and higher cycles, compared with the production and utilization of traditional biogas only. Also, upcycling of manure and crop residues as fertilizer will for example happen, as the substrate becomes a higher value digestate when leaving the reactor tank due to a mineralization of the substrate (Jørgensen, 2009). Thus, maintaining the quality of the resources at the same utility level is, as mentioned, not pursued in this case, as the analysis mainly is connected to upgrading/upcycling. An example could however be to utilize cereal straw as building materials, and hence make use of the residual straw for energy services when these buildings are demolished.

Below, the article shortly introduces wax and furfural that potentially can be extracted as bio-products from straw, as well as introduces, how proteins can be extracted from the green top of sugar beet, here relying on Danish experiences with grass clover.

\section{Bio-Products: Extraction of Wax, Furfural, and Protein}

Wax from straw: Waxes are a broad term and cover substrates as fatty alcohols, fatty acids, sterols, wax esters, alkanes, etc. Waxes can be produced from biomass residues such as palm leaves and cereal straw and are extracted from the greasy content on the cereal straw surface (Bulushi et al., 2018), and can serve various purposes as for example food supplements, cosmetics, flavorings, fragrances, and coatings (Sin et al., 2014). Wax made from biomass residues (natural wax) can substitute environmental unfriendly petroleum-based (fossil fuel) wax, which currently are limited in production scale (Bulushi et al., 2018). Natural wax can be extracted from cereal straw, by using supercritical $\mathrm{CO}_{2}$ acting as an extract-fluid/solvent (Hyatt, 1984; Hunt et al., 2010), which facilitates extraction and fractionation of wax from biomass, and can be carried out in an internal one step process (Deswarte et al., 2006; Sin, 2012). This method is thus a viable alternative to more traditional methods applying organic solvents, which are prohibited in substrates used in, e.g., cosmetics and food supplements, due to the fact that no solvent residues are produced when using supercritical $\mathrm{CO}_{2}$ (Hunt et al., 2010; Sin et al., 2014). According to Attard et al. (2015), Attard et al. (2016) is the use of supercritical $\mathrm{CO}_{2}$ as a first step in applying a bio-refinery where upcycling of downstream residues-thus low-value cascading's (see Figure 2 further below)—can be applied.

Furfural from straw: Furfural are regarded as important future bio-products and thus a platform for green chemicals and biofuels ( $\mathrm{Li}$ et al., 2016), and can be utilized as a "biobased alternative for the production of everything from antacids and fertilizers to plastics and paints" (Biomass Furfural, 2021). Traditional furfural is made from fossil fuel petroleum products where natural furfural is made from lignocellulosic comprising of lignin, hemicellulose, and cellulose. Xylose or xylan (hemicellulose) are often utilized to produce furfural using an acid catalyst, whereby hydrolysis of xylan into xylose appears, and a successive dehydration of xylose (pentose) then leads to the production of furfural. Xylan is found in lignocelluloses biomass, as for example cereal straw, maize cob, rice husk, bagasse, etc. (Matsagar et al., 2017). It is important to separate, hence pretreat, the lignocelluloses to be able to extract the content of hemicellulose, which then enables this substrate to be converted into C5 sugars and then finally into furfural. The production of furfur is, as mentioned, a chemical 


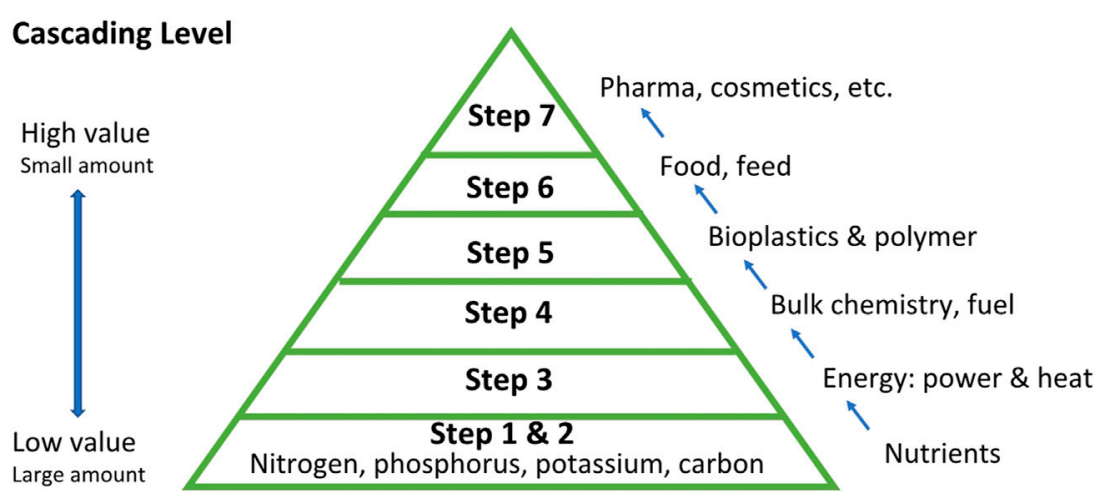

FIGURE 2 | Circular Bio-Economy (CBE) principles adopting Cascading of biomass residues.

platform - or building blocks - for producing various other types of green chemical and products and can also be facilitated by using supercritical $\mathrm{CO}_{2}$ (Sangarunlert et al., 2008). Hence, as for the case of wax, supercritical $\mathrm{CO}_{2}$ can be utilized as a solvent to extract furfural instead of environmental unfriendly mineral acid, where the recyclability of this solvent also is a major advantage.

Protein extraction from beet tops: Today, it is possible to use different technologies to extract edible protein concentrates from biomass residues to be used as food and fodder, in this case also from the green tops of sugar beet (Beta vulgaris L.). Experiments show that proteins can be extracted and fractionated from sugar beet tops by using a wet process to obtain two types of leaf protein concentrates. One, obtained by heat coagulation of the green juice with protein contents of approximately $34 \%$, and another, obtained from the brown juice with protein contents of $44 \%$, in both cases the results depend on the temperature and time used for extraction (Jwanny et al., 1993). Another method applied is to utilize enzymes to facilitate the process of extracting protein (Akyüz and Ersus, 2021).

Beet tops has historically been utilized for animal feed, but nowadays mostly left on the field to decompose or in some cases plowed into the soil for fertilizing, which is the same situation for residual straw (BioBIGG, 2020a). Literature state that beet-tops hold a protein content of 19-23\% (dry matter, DM) (Akyüz and Ersus, 2021). Little knowledge, however, exists on the extraction of proteins specifically from beet tops, whereas protein extraction-from within a Danish context-mostly has revolved around grass clover and extraction of proteins by a screw-pressers. This knowledge can most likely be transferred to extraction of proteins from beet-tops (University of Århus, 2015). Below, the article shortly presents the methods of extracting protein from green stuff, here exemplified by grass clover for animal fodder.

Newer research highlights (University of Århus, 2015; Santamaria-Fernandez et al., 2019; Frandsen, 2020) that the fiber/pulp fraction (70\% of the DM)-when feeding green stuff to a screw-presser-can be utilized for dairy cattle fodder and might thus improve the economy of utilizing green stuff, such as grass clover and beet tops, as protein fodder. Owing to a splitting up of the green fibers within the screw-presser, the cattle tend to be able to utilize

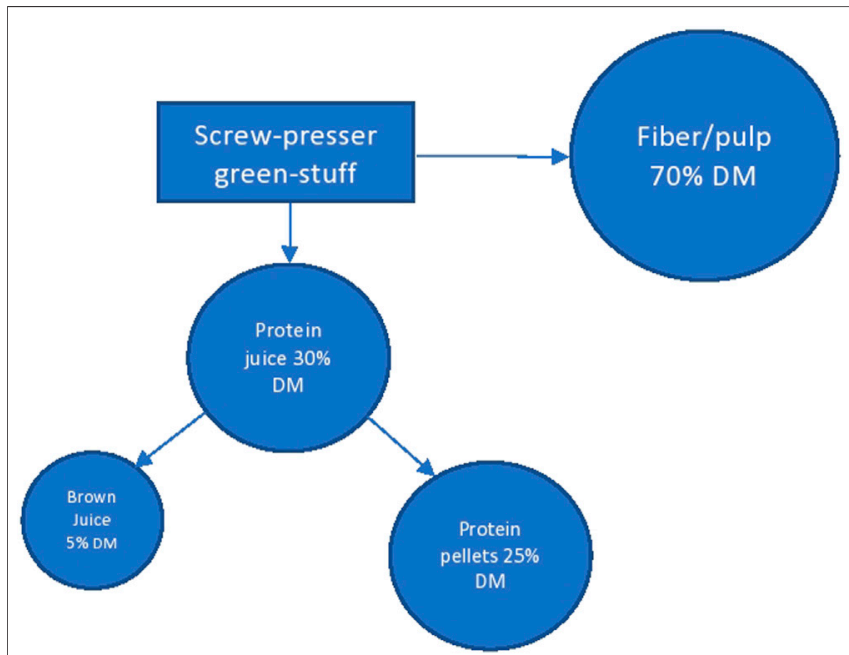

FIGURE 3 | Process of screw-pressing green stuff with high protein content as beet tops, grass-clover, etc. with output of 1) fiber/pulp for dairy cattle and 2) protein pellets for one-stomach-only livestock. Data from: (University of Århus (2015); Santamaria-Fernandez et al. (2019); Frandsen (2020).

the energy in the processed green stuff-the fiber/ pulp-better than ordinary green fodder, which they normally are feed by. A study further suggests that dairy cattle increase their milk yield production by as much as $37 \%$ when feed by fiber/pulp from green stuff, compared to ordinary non-processed green stuff (Damborg et al., 2019).

From the screw-presser, a juice (30\% of the DM)-being rich in proteins-is also extracted, which can be heated and turned into fodder pellets ( $25 \%$ of the DM), and usually utilized for onestomach livestock animals. The remaining part (5\% of the DM), which is a brown juice, can be utilized for biogas production, hence another upcycling in the cascading chain as far as energy production. See Figure 3 above:

Having outlived the theoretical lens and presented the bioproducts etc., being the main focus of this article, next is to present the data retrieval methods applied in this study, here also emphasizing our case study area. 


\section{Data Retrieval}

The data retrieval in this article is based on case study analysis, journal articles, and various literature studies. This will be detailed below.

\section{Case Study Research}

Within the Southern part of the island of Zealand, East Denmark, two municipalities are situated: Lolland \& Falster Municipalities. The two municipalities are mainly rural areas with various agricultural activities, hereunder the cultivation of cereal straw and sugar beet, of which the latter is intensively grown mainly for the local sugar industry. The area does not hold as much livestock as in the Western part of Denmark with more sandy soil. Unused agricultural residues are available within the municipalities, here emphasizing cereal straw and beet top residues. Also, un-digested animal manure is available, which all together could be utilized for energy production and bio-products in the future. The energy systems within the two municipalities are primarily based on collective district heating systems based on biomass (wood chips and straw), waste incineration, individual oil and gas boilers (which must be phased out), renewable energy from on-shore and off-shore wind turbines, as well as solar heaters. An extension of the natural gas pipelines from central Zealand is planned to be implemented in Lolland \& Falster Municipalities within the near future, emphasized later (Gaarsmand and Kjær, 2019).

Two biogas plants are scheduled to be implemented within Lolland \& Falster Municipalities, hence investigated in this article, with point of departure in the technology's capability to become a lever for future bio-product "extraction-activities" (here wax, furfural, and proteins), as well as higher value materials and energy output. Emphasis here is specifically on the Abed Biogas Plant, located in Lolland Municipality, as being representative for the two biogas plants placed in an area with no natural gas network. Political discussions, however, have been ongoing for several years now of whether or not to connect this area of Denmark to the natural gas network that exists in the remaining part of the region. This has, as of February 1,2021, been politically approved at a cost of 792 million DDK (106 million Euro) (Danish Ministry of Climate, Energy and Utilities, 2021), and more than 40 larger industries within the area-hereunder Nordic Sugar-have shown interest, where 15 industries already have signed "letters-of-interest" in purchasing gas from the coming gas network (SEAS-NVE, 2021).

\section{Literature}

Peer review articles, scientific reports, policy papers, and background literature, in general, have been utilized to qualify this article. This is for example literature from International Panel of Climate Change (IPCC), the European Union (EU), and the European Commission (EC) on climate change impacts and policies, as well as $\mathrm{CBE}$ initiatives. Besides this, data from the BioBIGG internal work reports have been utilized, e.g., mapping agricultural residues within the case area studied, as emphasized below. Furthermore, journal articles have been assessed to qualify statements further and to outline the CBE and cascading approach, as a theoretical framework in this article.

\section{Databases and Statistics}

Extensive data collection regarding biomass resources, as manure, residual straw, and beet tops, has been exercised as a precondition for this research paper and collected in the publications "Biomasse Potentialer" (Gaarsmand and Kjær, 2019) and "Biomass and innovation potential of residues, by-products and other sustainable feedstock for biobased products in four South Baltic Area regions" (Prade et al., 2019). Reference to this work thus provides condensed data and information, collected from agricultural databases, statistical information from, e.g., "Danish Statistic's," as well as various data from Danish governmental organizations, farmers organization, etc. on the amount and availability of biomass resources within Region Zealand. Besides this, data extraction from the "Technology Catalog" (Danish Energy Agency DEA, 2020b) has been utilized to calculate energy yields and estimate energy efficiencies, etc.

\section{RESULTS}

In the following, the results of this research project's mapping of agricultural residues within Region Zealand, as well as the potential energy output from the two biogas plants scheduled to be implemented within Lolland \& Falster Municipalities, are presented. Following that, a presentation of the technical concepts of the biogas plant at Lolland Municipality (the Abed Biogas Plants) is outlined, to access, whether CBE and cascading activities could be added to the existing design. This is in order to utilize the biogas plant as an "engine" for present and future production of bio-products and higher value materials and energy. Emphasis of the "engine" is, first, to apply solutions relying on internal technology and resources, as existing biogas technology and applicable technical solutions revolving around these, and to utilize readily available biomass residues from within the community. Second, in a later stage, utilization of other more advanced technical applications and additional biomass residues, from within or outside the community, can be "imported" to develop the production of bio-products and hence building blocks even further. Finally, the article presents a step-by-step approach of how to utilize the biomass residues identified, more efficiently, in a process where the biogas plant becomes an "engine" in which gradually higher cascading levels (upscalings) are achieved.

\section{Mapping Agricultural Residues}

Within Region Zealand approximately $7.3 \%$ of the arable land is cultivated with beet, which equals approximately 35.000 acres. The amount of sugar beet tops to reach 170.000 tons of Dry Matter (DM), with an average of 5 tons per acres, is identified (BioBIGG, 2020a). Besides this, 2.8 million tons of animal manure are produced on an annual basis within Region Zealand, of only which a minor part is being digested on the existing biogas plants, thus approximately 240.000 tons (Gaarsmand and Kjær, 2019). Cereal straw (winter wheat and other cereals) covers approximately $71 \%$ of the arable land and 
TABLE 1 | Technical concept-Example of Abed Biogas Plant (Lolland Kommune, 2020).

Biogas yield $\mathrm{m}^{3} / \mathrm{y}$ (methane)
Energy production MWh/y
\# of households receiving energy services
Storage capacity of raw biogas (tons)
Use of feedstock annually (tons)
\# of pre-storage tanks
Plan level storage facility (acres)
\# of reaction tanks (height $26 \mathrm{~m}$ )
\# of storage tanks for digested substrate
\# of gas storage tanks
Technical applications

Buildings
20

198.500

14.000

10

600.000

Several

2-4

6

Several

Several

Bridge weight

Boiler plant

Air cleaning facility

Sulfur cleaning facility

Gas upgrading plant

Gas flaring unit

Connection to natural gas network

Administration house

Barnes for unloading biomass substrate

Barnes containing biomass pre-treatment technology 39 take up 310.000 acres at Region Zealand, providing cereal crop yields of approximately 1.4 million tons per year. It is estimated that approximately $35 \%$ of the residual straw currently left on the farmland are collected and utilized for combined heat and power production (CHP) on decentralized CHP plant within the Region (BioBIGG, 2020b). Small fractions are also utilized for animal bedding materials, fodder and in individual straw fired farm boilers, but the largest part is yet to find other means of usage, as simply decomposing on farmland.

Within Falster \& Lolland Municipalities specifically, it is identified that 800.000 tons of animal manure are readily available for biogas production, within a distance of $30 \mathrm{~km}$ from the two suggested plant location sites. Besides this, 880.000 tons of unused beet tops and 220.000 tons of residual straw from the community are assessed to theoretically be feed to the biogas facilities. For the planned biogas plants within Lolland \& Falster Municipalities, the following biomass resources have been estimated to be readily available: The full manure potential equal to 800.000 tons; 230.000 tons sugar beet tops; 100.000 tons of residual straw, thus approximately 1.130 .000 tons (Gaarsmand and Kjær, 2019; Prade et al., 2019).

\section{Energy Production and Technical Plant Specifications}

The potential gas yield from the two biogas plants that are scheduled to be operated as manure-based biogas plants, mixed with green substrates to utilize the available biomass resources from the community, is assessed as follows. The total energy output from the two plants is estimated to be 40 million $\mathrm{m}^{3}$ biogas (methane) which equals $397.000 \mathrm{MWh}$ (estimated by the lower calorific value of $9.94 \mathrm{kWh} / \mathrm{m}^{3}$ (Danish Energy Agency DEA, 2020a). The fertilizer yield is assessed to reach 5.500 tons of nitrogen $(\mathrm{N})$ and the total greenhouse gas (GHG) reductions to 169,220 tons of $\mathrm{CO}_{2}$ eq. (Prade et al., 2019). The technical specifications related to the plant layout at the Abed Biogas Plant are exemplified in Table 1.

The biogas concept presented above is, as mentioned earlier, one of two plants schedules to be implemented within Lolland \& Falster Municipalities. The technical concepts rely on mature and reliable biogas technology that has been operated in a Danish context for several years (Holm-Nielsen et al., 2009; Jørgensen, 2009; Food and Bio Cluster Denmark, 2020). As seen from the technical concept in Table 1, Lolland Municipality emphasize on upgrading biogas to natural gas standards, as a consequence of the natural gas pipeline that will be in operation in 2024 (SEASNVE, 2021). It is also clear that the municipality plan to use a little more than half of the biomass residues that was found appropriate, hence 600.000 tons annually.

There are, however, no current plans of applying solutions that emphasize the production of bio-products in the technical concept presented, nor any plans of how to utilize the specific residues from the local area more efficiently than simply as a biosubstrate to be mixed with manure. In the following, the article discusses how the biogas plant can be optimized, applying the normative lens of $\mathrm{CBE}$ adopting applicable cascading opportunities offered by the specific context. This is detailed in the following.

\section{Biogas as "Engine" for Bio-Products and Higher Value Materials and Energy}

Below, it is identified how bio-product "extraction-activities" for cereal straw and beet tops can be obtained when connecting and integrating such resources to a biogas "engine" technology, where various cascading's move the system to a higher level. The approach is, as mentioned, to look at options for extracting protein from beet tops, and furfural (from C5 sugars) and wax 
(fatty alcohols, alkanes) from residual straw (Sin, 2012; Matsagar et al., 2017), as well as to obtain higher value of materials and energy. The notion of using the biogas technology as an "engine" is understood as the technology's capability to become a "hub" for activities, like thermal, mechanical, biological, and chemical treatment, enabling production of bio-products and higher value materials and energy. "Engine" is thus interpreted as biogas technology being a "multiple treatment/production facility."

As illustrated in Figure 2, the aim is to develop a method in which biomass residues and side streams are utilized efficiently, and where the development of the system happens in steps according to whether or not they can be deployed based on internal CBE processes at the initial stage, without drawing on "imports" of other types of external biomass resources or highly advanced and costly technology. Having developed such internal CBE processes, emphasis could then be to develop CBE processes relying on additional residues and the production of other types of bio-products. This is emphasized in the following and depicted in Figure 2, showing the cascading chain.

The lower step (1) in the cascading chain is the recirculation of nutrients, such as nitrogen, phosphorous, and potassium, which is pivotal to sustain farmland fertility and hence the cultivation of crops etc. This is based on the agricultural sectors production of animal manure, where this substrate is recirculated as a fertilizer. At this level, however, it is possible not only to utilize the nutrients in the animal manure, but also to include local waste streams such as various crop residues to provide valuable soil nutrient, in this case straw and beet tops. The biomass resources (manure and crops residues) should preferably not be utilized as fertilizer on farmland being un-digested, emphasized in the following step. Hence, the next step (2) includes the benefits of the biogas technology as far as mineralization of nutrients, odor reduction, and the ease of distributing the digestate on farmland after the substrate has been digested and thus becomes more liquid (Jørgensen, 2009; Al Seadi et al., 2013b). This step increases the cascading value of both manure and biomass crop residues. Thus, higher value materials are obtained.

In step (3) the substrate-and consequently gas production from the reactor tanks-is additionally utilized for renewable energy production as Combined Heat and Power (CHP), which faces out/reduces the consumption of fossil fuels within the local energy system, hereby increasing the level of cascading even further (upcycling). In Step (4) some, or all, of the biogas is upgraded to bio-methane, by the extraction of the content of $\mathrm{CO}_{2}$. This enables the bio-methane (upgraded biogas) to be distributed to other parts of Region Zealand through the natural gas network, and hence to supply more flexible and higher value energy services with better storage options as a benefit (Dansk Gasteknisk Center, 2019; 2020; SEAS-NVE, 2021). This is also in line with the EC's ambitions of developing more integrated energy systems within the EU (European Commission, 2020). Thus, higher value energy services are obtained. The scheduled biogas plant at Abed entails until step (4).

In step (5) the use of the biomass residues, and the production of $\mathrm{CO}_{2}$ from the upgrading of biogas, now enables the use of straw and beet tops residues in a completely other order, which increases the cascading value of the entire process. It is suggested to utilizing the straw for extraction of bio-products, as for example wax and furfural, where the processed/extracted residual straw are feed to the biogas plant as feedstock afterward (see Figure 4). This process can be applied as an internal process using the extracted $\mathrm{CO}_{2}$ from the upgrading of biogas, as supercritical $\mathrm{CO}_{2}\left(\mathrm{scCO}_{2}\right)$, a solvent, to extract furfural and wax. Being an internal process, not relying on outside "import" of highly advanced technology, such bio-products could be produced before other types of bio-products. During the extraction of wax and furfural the residual straw undergoes a pretreatment in which it becomes highly appropriate for biogas production. Hence, it turns to a higher value substrate in the cascading process, with gas yields surpassing the level of the nonprocessed straw residues. As a consequence of this, expenses connected to previous pretreatment technologies of straw, such as macerator, choppers etc. might be avoided (Møller and Nielsen, 2016). Synergies will hence be obtained.

Besides recirculation of nutrients (step 1), digestion of manure and biomass residues within the biogas technology (step 2), renewable energy production as CHP to local community (step 3), upgraded biogas to the natural gas network within Region Zealand (step 4), and furfural and wax extraction from straw (step 5), the next step (6) - in this specific case-is to utilize the residual beet tops for production of proteins before feed to the biogas plant. Thus, the green top can be used for high value protein extraction for human and animal feed, by using a screwpressers, as exemplified earlier in this article (see Figure 2). By extracting the protein from beet tops the crop is utilized at the highest cascading level as possible, where the remaining residues can be utilized together with straw for biogas production, preferably as silage materials, emphasized shortly below. The brown juice from the protein production can, however, be feed directly to the biogas plant, also pointed out earlier in Figure 2.

To move the use of beet-tops and straw to an even higher cascading level, as far as gas yield, the protein extracted beet tops can be mixed and stored as silage together with residual straw, as the straw stabilizes the beet tops whereby the gas yield increases, as opposed to a separate storage and silage. Besides this, the green beet tops will soften the lignin content in the straw, whereby microorganisms within the reactor tank have better access to the hemicelluloses (Møller and Nielsen, 2016; Lybæk et al., 2020). Data regarding the use of straw for the production of wax and furfurals, as well as pretreatment costs and gas yield etc. connected to the use of residual straw at the Abed Biogas Plant, are exemplified in Figure 4.

Applying any further steps in the cascading chain could be to produce second-generation bioethanol with the use of enzymes, which however require the implementation of additional technology and facilities. Such extraction-activity should however happen before any residual substrates are feed to the biogas plant as feedstock. Another option is to include additional types of biomass residues from the local community than those presented previously. This could for example be forest wood waste for the production, e.g., polymers, which again will require implementation of new advanced technology and facilities. Besides this, methanization of $\mathrm{CO}_{2}$ can be applied if sufficient 


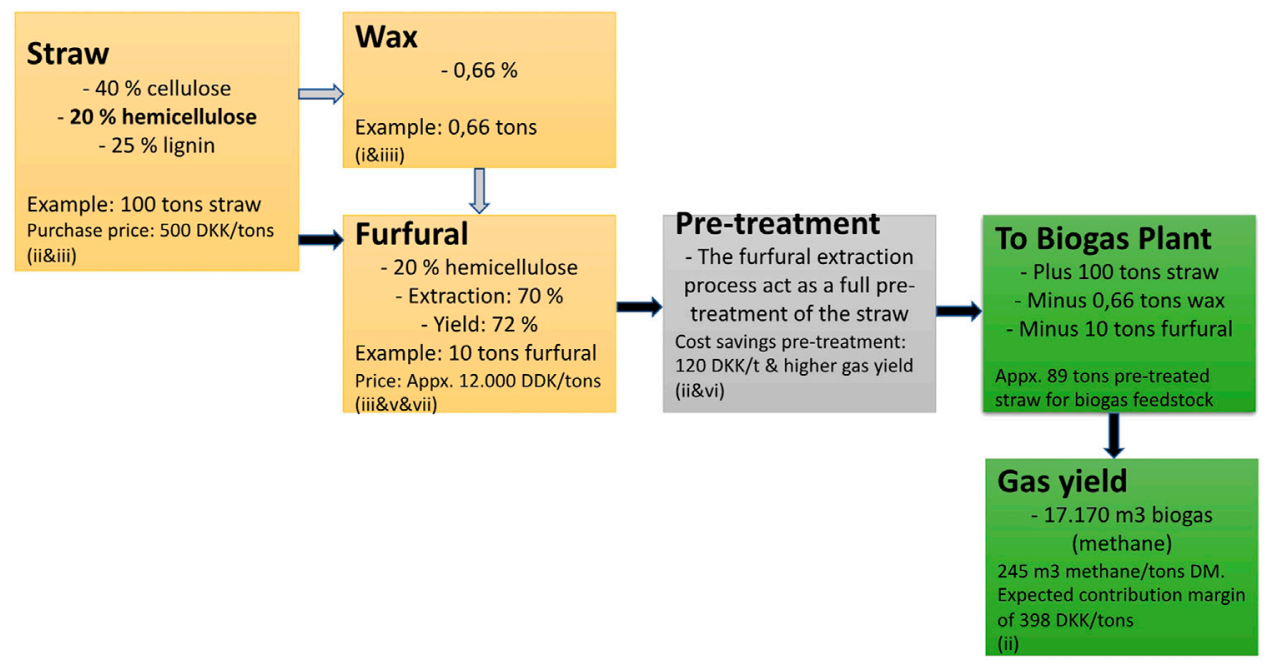

FIGURE 4 | Internal use of straw residues, supported by well-known and mature biogas technology using supercritical CO2 from the internal process of upgrading biogas, including producing wax and furfural. 100 tons of residual straw equals 1/100 of the amount that will be digested at Abed Biogas Plant. (Sources: Sin et al., 2014 (i); Møller and Nielsen, 2016 (ii); Matsagar et al., 2017 (iii); Bulushi et al., 2018 (iv); Dalvand et al., 2018 (v); Lybæk et al., 2020 (vi); Biomass Furfural, 2021 (vii)).

quantities are available, using hydrogen $\left(\mathrm{H}_{2}\right)$ from the production of wind and solar energy, and hence strengthen a more integrated energy system within Region Zealand. The latter suggestions require highly advanced and expensive technologies but could be viably in a later stage of the production of bio-products/ building blocks.

Thus, the important aspect here is to apply a method, which step-by-step increases the use of side streams, and constantly seeks to upcycle biomass residues to bio-product and achieve higher value materials and energy. The extraction activities must be applied before other types of activities, as for example biogas production. Thus, the hierarchy of using the biomass residues for bio-products must thus be prioritized, before using it as feedstock for the production of biogas. Moreover, biomass residues from within the local community should, hierarchically, be utilized before "imports" of other types of biomass from outside the area to enhance the circularity within the local community. Finally, priority should be given to develop internal CBE processes, which the existing biogas technology can enable and sustain, before later on emphasizing on development of processes that entails implementation of more advanced and costly technologies and facilities.

\section{DISCUSSION}

The step-by-step approach developed in this article proposes that mature and reliable biogas technology becomes an "engine" for an efficient use of biomass for production of bio-products. Such bio-products have previously been tried to be produced on very advanced bio-refineries in a Danish context, but with little success and large economic costs as a consequence. Three biorefineries connected to the Danish energy company Ørsted have for example been terminated, being "Inbicon" (Larsen et al., 2012) and "Pyroneer" (Viader, 2016) both emphasizing biomass residues, as well as "REnescience" (Global Recycling, 2021) focusing organic waste from households. Besides this, the Maabjerg BioRefinery project were never really initiated due to political, regulatory, and economic restrictions (Lybæk et al., 2020), despite large fundings and high ambitions. This article therefore suggests developing smaller and simpler "biorefineries" based on the concept of mature and reliable biogas technology, which enables and becomes an "engine" in a gradually expanded production of biorefinery products. In this way the production of bio-products, thus building blocks, happens gradually and might enable, economically and technically, that the ambitious climate targets formulated by Region Zealand can become reachable.

The production of "building blocks," as suggested above, has also recently been included in a new Danish governmental action plan emphasizing a "National Bioeconomic Strategy" (Ministry of Food, Agriculture and Fisheries of Denmark, 2020). Focus is on the role of biomass, such as crops, biomass residues, and side streams etc., where waste materials according to the strategy must play a vital role in the Danish economy. New investigations will show how land use, biomass, and bio-refining can provide socioeconomic gains for the future. Legal requirements will for example be formulated for the sustainability of wood biomass usage, and with the "National Bioeconomic Strategy" a "green billion" (13,33 million Euro) has been channeled to research and development of a green transition pathway. The funds will be used to, e.g., promote bio-economic potentials, including testing, development, establishment, and demonstration of technical solutions in the field of biorefining (Ministry of Food, Agriculture and Fisheries of Denmark, 2020). Thus, other types of biorefineries might emerge in the future, which emphasize less on more advanced solutions in the initial stage, 
but mature and reliable existing solutions and techniques, which immediately can be adopted as an "engine" in the production of bio-products and higher value materials and energy.

\section{CONCLUSION}

This article exemplifies how residual biomass from within Region Zealand can be utilized efficiently for bio-products and in the achievements of higher value materials and energy. Emphasis has been on a biogas plant in Lolland Municipality, the Abed Biogas Plant, and the utilization of manure, straw, and beet top residues generated within the local community, as feed stock for the biogas plant. A step-by-step approach has been developed, which can facilitate a more efficient use of such resources. Within Denmark as a whole (Wittrup and Jeppesen, 2020), and Lolland \& Falster Municipalities exemplified here, residual straw and beet tops are highly available. However, emphasis should not only be on these specific agricultural residues, but also on other agricultural residues, and residues from the forestry sector, as well as from the industry and household sector, where large unused potentials of organic waste materials and residues exist (Gaarsmand and Kjær, 2019; Prade et al., 2019). In the specific contexts addressed, the biomass availability must be mapped, and the energy system accessed, to decide how the step-by-step approach should be utilized the most appropriate for production of bio-products (building blocks), and higher value materials and energy.

At the global level it is favorable to implement the proposed system, given the specific context, as environmental benefits will be achieved at several levels. First, the biomass will be utilized more efficiently, as wax and furfural-valuable industrial resources for, e.g., pharmaceutical products-will be extracted before the biomass residues are used for energy purposes. Efficiency in biomass utilization gradually becomes more

\section{REFERENCES}

Akyüz, A., and Ersus, S. (2021). Optimization of Enzyme Assisted Extraction of Protein from the Sugar Beet (Beta Vulgaris L.) Leaves for Alternative Plant Protein Concentrate Production. Food Chem. 335, 127673. doi:10.1016/ j.foodchem.2020.127673

Al Seadi, T., Rutz, D., and Janssen, R. (2013a). "Biomass Resources for Biogas Production," in The Biogas Handbook - Science, Production and Applications. Editors A. Wellinger, J. Murphy, and D. Baxter (Cambridge, UK: IEA Bioenergy. Woodhead Publishing Limited), 19-51.

Al Seadi, T., Drosg, B., and Fuchs, W. (2013b), Biogas Digestate Quality and Utilization. The Biogas Handbook - Science, Production and Applications. Editors D. Rutz, R. Janssen, and D. Baxter, 267-301. Cambridge, UK: IEA Bioenergy. Woodhead Publishing Limited. doi:10.1533/9780857097415.2.267

Attard, T., McElroy, C., and Hunt, A. (2015). Economic Assessment of Supercritical CO2 Extraction of Waxes as Part of a Maize Stover Biorefinery. Int. J. Mol. Sci. 16 (8), 17546-17564. doi:10.3390/ijms160817546

Attard, T. M., McElroy, C. R., Gammons, R. J., Slattery, J. M., Supanchaiyamat, N., Kamei, C. L. A., et al. (2016). Supercritical CO2Extraction as an Effective Pretreatment Step for Wax Extraction in a Miscanthus Biorefinery. ACS Sustain. Chem. Eng. 4 (11), 5979-5988. doi:10.1021/acssuschemeng.6b01220

Beuse, E. (2000). Vedvarende Energi I Danmark - En Krønike Om 25 Opvoekstår 1975-2000. OVEÅrhus, Denmark: Organisationen for Vedvarende EnergiOVE. important, as our energy supply and materials use are converted into renewable energy and bio-degradable products based on various sorts of biomass. Second, production of wax and furfural currently relies on petroleum-based products, which harm the environment significantly (Matsager et al., 2017). The production is currently limited, however, but the request for these products is high. Thus, a larger production of natural furfural and natural wax, from the biogas system proposed in this article, will provide environmental benefits and increase the production of these materials for producing "building blocks," as well as resources for the industry.

\section{DATA AVAILABILITY STATEMENT}

The raw data supporting the conclusions of this article will be made available by the authors, without undue reservation.

\section{AUTHOR CONTRIBUTIONS}

$\mathrm{RL}$ and TK contributed to the conception and design of the study. TK organized the dataset and statistical analysis. RL wrote the first draft of the paper, as well as the remaining sections of the manuscript. Both RL and TK contributed to the manuscript revision, read and approved the final and hence submitted version.

\section{FUNDING}

Interrreg South Baltic and Region Zealand entitled: "BioBIGGBioeconomy in the south Baltic Area: Biomass-based Innovation and Green Growth”. BioBIGG, j.nr. STHB.01.02.00-DK0086/ 16-00.

BioBIGG (2020a). Residues from the Sugar Value Chain. Available at: https://biobigg. ruc.dk/residues-from-the-sugar-value-chain/ (Accessed Feburary 12, 2021).

BioBIGG (2020b). Mapping of Residues from the Cereal Production Value Chain. Available at: https://biobigg.ruc.dk/straw-value-chain/ (Accessed March 16, 2021).

Biomass Furfural (2021). Future Feedstock for Fuels and Chemicals. Available at: http://biomassmagazine.com/articles/1950/furfural-future-feedstock-for-fuelsand-chemicals (Accessed September 5, 2020).

Bulushi, K. A., Attard, T. M., North, M., and Hunt, A. J. (2018). Optimization and Economic Evaluation of the Supercritical Carbon Dioxide Extraction of Waxes from Waste Date palm (phoenix Dactylifera) Leaves. J. Clean. Prod. 186, 988-996. doi:10.1016/J.JCLEPRO.2018.03.117

Dalvand, K., Rubin, J., Gunukula, S., Clayton Wheeler, M., and Hunt, G. (2018). Economics of Biofuels: Market Potential of Furfural and its Derivatives. Biomass and Bioenergy 115, 56-63. doi:10.1016/j.biombioe.2018.04.005

Damborg, V. K., Jensen, S. K., Johansen, M., Ambye-Jensen, M., and Weisbjerg, M. R. (2019). Ensiled Pulp from Biorefining Increased Milk Production in Dairy Cows Compared with Grass-clover Silage. J. Dairy Sci. 102 (10), 8883-8897. doi:10.3168/jds.2018-16096

Danish Energy Agency DEA (2020a) Liste over Biogasanlæg I Danmark 2020. Available at: https://ens.dk/sites/ens.dk/files/Bioenergi/anlaegsoversigt_2020. pdf. (Accessed August 9, 2020).

Danish Energy Agency DEA (2020b). Technology Catalog. Available at: https:// ens.dk/en/our-services/projections-and-models/technology-data (Accessed January 8,2021 ). 
Danish Ministry of Climate Energy and Utilities (2020). Climate Deal Energy And Industry 2020. Danish Government. Copenhagen, Denmark. Available at: https://www.regeringen.dk/publikationer-og-aftaletekster/klimaaftale-for-energiog-industri-mv-2020/ (Accessed Decmeber 21, 2020).

Danish Ministry of Climate Energy and Utilities (2018). Energy Deal 2018. Danish Government, Copenhagen, Denmark. Available at: https://kefm.dk/media/ 6646/energiaftale_2018.pdf (Accessed March 29, 2021).

Danish Ministry of Climate Energy and Utilities (2021). Gasledning Til LollandFalster Skal Sikre CO2-reduktioner Og Arbejdspladser. Available at: https:// kefm.dk/aktuelt/nyheder/2021/feb/gasledning-til-lolland-falster-skal-sikreco2-reduktioner-og-arbejdspladser (Accessed March 14, 2021).

Dansk Energi (2017). Landsbyvarme Kan Bryde Afhængighed Af Olie. Available at: https://www.danskenergi.dk/nyheder/landsbyvarme-kan-bryde-afhaengighedolie (Accessed March 14, 2021).

Dansk Gasteknisk Center (2019). Gasfaglig indsats 2019 - Energikonvertering: Et overblik over gassens integration i et bæredygtigt energisystem. Available at: https://www.dgc.dk/sites/default/files/filer/publikationer/Gasfaglig/indsats/ 2019_final.pdf (Accessed December 12, 2020).

Dansk Gasteknisk Center (2020). Global Undersøgelse Af Power-To-Hydrogen Og Power-To-Methane Projekter. Available at: https://www.dgc.dk/sites/default/ files/filer/publikationer/P2X_teknologier.pdf (Accessed December 11, 2020).

Deswarte, F. E. I., Clark, J. H., Hardy, J. J. E., and Rose, P. M. (2006). The Fractionation of Valuable Wax Products from Wheat Straw Using CO2. Green. Chem. 8 (1), 39-42. doi:10.1039/b514978a

European Comission (2020). Powering a Climate-Neutral Economy: An EU Strategy for Energy System Integration. Brussels, 8.7.2020 COM (2020) 299 final. Available at: https://www.actu-environnement.com/media/pdf/news35816-systeme-integration-energie.pdf (Accessed January 9, 2021).

European Commission (Ec) (2018). A Sustainable Bioeconomy for Europe: Strengthening The Connection between Economy. Updated Brussel Belgium: society and the environment.

European Commission (Ec) (2012). Innovating for Sustainable Growth: A Bioeconomy for Europe. Brussel, Belgium.

Fælles Regional Energiomstilling (2020). Energipolitisk Charter - Charter For Kommunerne I Region Sjoelland. Region Zealand, Denmark. Available at: https://www.gate21.dk/faelles-regional-energiomstilling/ (Accessed January 10, 2021).

Food and Bio Cluster Denmark (2020). Biogas Production - Insights and Experiences from the Danish Biogas Sector. Denmark: Biogas Go GlobalTjele.

Frandsen, T. Q. (2020). Synergi Mellem Grøn Bioraffinering Og Biogasproduktion. Teknologisk Institut, Denmark. Available at: https://www.biogas2020.se/wpcontent/uploads/2017/11/nr-6-synergi-biogas-bioraffinering-tqf.pdf (Accessed March 9, 2021).

Fuel Cell Bulletin (2020). Funding For Two Large-Scale Power-To-X Projects in Denmark. Available at: https://pdf.sciencedirectassets.com/272109/1-s2.0S1464285920X70015/1-s2.0-S1464285920300249/main.pdf (Accessed March 9, 2021).

Fund, C., El-Chichakli, B., and Patermann, C. (2018). Bioeconomy Policy (Part III): Update Report on International Strategies Around the World. Berlin, Germany: German Bio-economic Council. Available at: https://biooekonomierat.de/ fileadmin/Publikationen/berichte/GBS_2018_Bioeconomy-Strategies-aroundthe_World_Part-III.pdf (Accessed February 22, 2020).

Gaarsmand, R., and Kjær, T. (2019). Biomasse Potentialer - Energi Og Bioøkonomiske Biomasse Potentialer. Roskilde, Denmark: IMT. Roskilde University.

Global Recycling (2021). REnescience: A New Technology with Global Ambitions. Available at: https://global-recycling.info/archives/855 (Accessed March $13,202)$.

Gylling, M., Jørgensen, U., and Bentsen, N. S. (2012) + 10 mio. tons planen muligheder for en øget dansk produktion af bæredygtig biomasse til bioraffinaderier, Frederiksberg, 2012. $32 \mathrm{~s}$. ill. Available at: https://cbio.au. dk/fileadmin/ti-mio-plan_2012.pdf (Accessed February 25, 2021)doi:10.7146/ nfg.v20i19.23654

Hetemäki, L., Hanewinkel, M., Muys, B., Ollikainen, M., Palahí, M., and Trasobares, A. (2017). Leading the Way to a European Circular Bioeconomy Strategy. Sci. Pol. 5. doi:10.36333/fs05 (online) Available at: https://www.researchgate.net/publication/320735118_Leading_the_way_to_ a_European_circular_bioeconomy_strategy\#fullTextFileContent (Accessed
December 7, 2019), 1-52. //https://efi.int/sites/default/files/files/publicationbank/2019/efi_fstp_5_2017.pdf

Holm-Nielsen, J. B., Al Seadi, T., and Oleskowicz-Popiel, P. (2009). The Future of Anaerobic Digestion and Biogas Utilization. Bioresour. Techn. 100 (22), 5478-5484. doi:10.1016/j.biortech.2008.12.046

Hunt, A. J., Sin, E. H. K., Marriott, R., and Clark, J. H. (2010). Generation, Capture, and Utilization of Industrial Carbon Dioxide. ChemSusChem 3 (3), 306-322. doi:10.1002/cssc.200900169

Hyatt, J. A. (1984). Liquid and Supercritical Carbon Dioxide as Organic Solvents. J. Org. Chem. 49 (26), 5097-5101. doi:10.1021/jo00200a016

Jørgensen, P. J. (2009). Biogas - Green Energy. 2nd edition. Editor A. B. Nielsen. Denmark: Faculty of Agricultural Sciences, Århus University. Available at: https://www.lemvigbiogas.com/BiogasPJJuk.pdf.

Jwanny, E. W., Montanari, L., and Fantozzi, P. (1993). Protein Production for Human Use from Sugarbeet: Byproducts. Bioresour. Techn. 43, 67-70. Available at: https://www.sciencedirect.com/science/article/abs/pii/096085249390085P\#! (Accessed August 10, 2018). doi:10.1016/0960-8524(93)90085-p

Larsen, J., Haven, M. Ø., and Thirup, L. (2012). Inbicon Makes Lignocellulosic Ethanol a Commercial Reality. Biomass and Bioenergy 46, 36-45. doi:10.1016/ j.biombioe.2012.03.033

Li, X., Jia, P., and Wang, T. (2016). Furfural: A Promising Platform Compound for Sustainable Production of C4and C5Chemicals. ACS Catal. 6, 7621-7640. doi:10.1021/acscatal.6b01838

Lolland Kommune (2020). Idéopleg Til Biogasanleeg Ved Abed. Danmark: Lolland Kommune.

Lybæk, R., Christensen, T. B., and Kjær, T. (2013). Governing Innovation for Sustainable Development in the Danish Biogas Sector - an Historical Overview and Analysis of Innovation. J. Sustain. Dev. 21 (3), 171-182. doi:10.1002/ sd. 1548

Lybæk, R., Christensen, T. B., and Thomsen, T. P. (2020). Enhancing Policies for Deployment of Industrial Symbiosis: What Are the Obstacles, Drivers and Future Way Forward? J. Clean. Prod. 280 (2), 124351

Lybæk, R., Kjær, T., and Hauggaard-Nielsen, H. (2020). Can the Area of Organically Cultivated Arable Land Increase when Utilizing Perennial Grasses as Feedstock for Biogas Production? GMSARN Int. J. 14 (4), 178-184.

Malico, I., Nepomuceno, R., Gonçalves, A. C., Sousa, A. M. O., and Sousa, A. M. O. (2019). Current Status and Future Perspectives for Energy Production from Solid Biomass in the European Industry. Renew. Sustain. Energ. Rev. 112, 960-977. doi:10.1016/j.rser.2019.06.022

Matsagar, B. M., Hossain, S. A., Islam, T., Alamri, H. R., Alotham, Z. A., Yamauchi, Y., et al. (2017). Direct Production of Furfural in One-Pot Fashion from Raw Biomass Using Brønsted Acidic Ionic Liquids. Sci. Rep. 7, 13508. doi:10.1038/ s41598-017-13946-4

Ministry of Food, Agriculture and Fisheries of Denmark (2020). Handlingsplan For Nye Og Bærerdygtige Byggeklodser. Available at: https://mfvm.dk/fileadmin/ user_upload/MFVM/Miljoe/Biooekonomi/Handlingsplan_for_nye_baeredygtige_ byggeklodser.pdf (Accessed March 25, 2021).

Møller, H. B., and Nielsen, K. J. (2016). Biogas Task Force - Udvikling Og Effektivisering Af Biogas Produktion I Danmark. Faglig Rapport. Århus, Denmark: Århus University and Plan Energy. Available at: https://dcapub. au.dk/djfpublikation/djfpdf/DCArapport077.pdf (Accessed February 1, 2021).

Pfau, S., Hagens, J., Dankbaar, B., Smits, A., and Smith, J. M. (2014). Visions of Sustainability in Bioeconomy Research. Sustainability 6 (3), 1222-1249. doi:10.3390/su6031222

Prade, T., Andrzejczyk, R., Booker Nielsen, M., Cuypers, B., Dąbrowski, P., Ekman, A., et al. (2019). Biomass And Innovation Potential of Residues, By-Products and Other Sustainable Feedstock for Biobased Products in Four South Baltic Area Regions, Interreg Project Bioeconomy in the South Baltic Area: BiomassBased Innovation and Green Growth - BioBIGG. Available at: https://issuu. com/biobigg/docs/biomass_and_innovation_potential_of_residues_by-p (Accessed December 21, 2020 Decmber 18, 2020).

Raven, R. P. J. M., and Gregersen, K. H. (2007). Biogas Plants in Denmark: Successes and Setbacks. Renew. Sustain. Energ. Rev. 11 (1), 116-132.

Rüdiger, M. (2014). "The 1973 Oil Crisis and the Designing of a Danish Energy Policy. Historical Social Research), 39 (4), 94-112. Available at: https://www. ssoar.info/ssoar/bitstream/handle/document/40489/ssoar-hsr-2014-4-rudigerThe_1973_oil_crisis_and.pdf?sequence $=1$ \&isAllowed $=y \&$ Inkname $=$ ssoar-hsr2014-4-rudiger-The_1973_oil_crisis_and.pdf. 
Sangarunlert, W., Piumsomboon, P., and Ngamprasertsith, S. (2008). Furfural Production by Acid Hydrolysis and Supercritical Carbon Dioxide Extraction from rice Husk. Korean J. Chem. Eng. 24, 936-941.

Santamaria-Fernandez, M., Ambye-JensenDamborg, M. V. K., and Lübeck, M. (2019). Demonstration-scale Protein Recovery by Lactic Acid Fermentation from Grass clover - a Single Case of the Production of Protein Concentrates and Press Cake Silage for Animal Feeding Trials. Biofuels, bioproducts and biorefining 13 (3), 502-513.

SEAS-NVE (2021). Ny Gasledning På Vej Til Lolland-Falster. Available at: https:// www.seas-nve.dk/erhverv/naturgas/ny-gasledning-kan-starte-biogas-eventyrpaa-lolland-falster.

Sin, E. H. K., Marriott, R., Hunt, A. J., and Clark, J. H. (2014). Identification, Quantification and Chrastil Modelling of Wheat Straw Wax Extraction Using Supercritical Carbon Dioxide. Comptes Rendus Chim. 17, 293-300. doi:10.1016/ j.crci.2013.12.001

Sin, E. H. K. (2012). The Extraction and Fractionation of Waxes from Biomass. USA, New York: University of New York, Department of Chemistry. PhD thesis. Available at: https://etheses.whiterose.ac.uk/3123/.

Sirkin, T. (1990). Cascading: A Tool for Resource Conservation. Copenhagen, 2, 16-17. O2.

Sirkin, T., and ten Houten, M. (1994). The cascade Chain: A Theory and Tool for Achieving Resource Sustainability with Application for Product Design, Resource, Conservation and Recycling 10, 77-213. doi:10.1016/0921-3449(94)90016-7

Stegmann, P., Londo, M., and Junginger, M. (2020). The Circular Economy: Its Elements and Role in the European Bioeconomy Clusters. Resource, Conservation \& Recycling X (6), 100029. doi:10.1016/j.rcrx.2019.100029

IPCC (2013). Climate Change 2013: The Physical Science Basis. Contribution of Working Group I to the Fifth Assessment Report of the Intergovernmental Panel on Climate Change. Editors T.F. Stocker, D. Qin, G.-K. Plattner, M. Tignor, S.K. Allen, J. Boschung, et al. (Cambridge, United Kingdom and New York, NY, USA: Cambridge University Press), 1535.

University of Århus (2015). Grøn Biomasse - DCA Rapport Nr. 068. Århus, Denmark. Available at: https://anis.au.dk/fileadmin/DJF/DCA/Bibliotek/Pdf_ dokumenter/Uddrag_DCArapport068.pdf (Accessed April 5, 2021).

Viader, R. P. (2016). Upgrading and Recovery of Fertilizer Value of Ash from PYRONEER Gasification of Low Value and Difficult Biomass feedstockPhD Thesis. DTU, Lyngby, Denmark: Danish Technical University.

Wittrup, S., and Jeppesen, M. E. (2020). Rådnende halm fra markerne skal ind i energiforsyningen. Ingeniøren 37, 4-5.

Conflict of Interest: The authors declare that the research was conducted in the absence of any commercial or financial relationships that could be construed as a potential conflict of interest.

Publisher's Note: All claims expressed in this article are solely those of the authors and do not necessarily represent those of their affiliated organizations, or those of the publisher, the editors and the reviewers. Any product that may be evaluated in this article, or claim that may be made by its manufacturer, is not guaranteed or endorsed by the publisher.

Copyright (C) 2021 Lyboek and Kjor. This is an open-access article distributed under the terms of the Creative Commons Attribution License (CC BY). The use, distribution or reproduction in other forums is permitted, provided the original author(s) and the copyright owner(s) are credited and that the original publication in this journal is cited, in accordance with accepted academic practice. No use, distribution or reproduction is permitted which does not comply with these terms. 